\title{
AGRICULTURAL LAND AND ACTIVITIES IN MUREȘ COUNTY
}

\author{
George-Bogdan TOFAN* \\ "Vasile Goldiş" Western University of Arad, Faculty of Economic Sciences, Engineering and Informatics, Departament of \\ Engineering and Informatics, Baia Mare Branch, 5 Culturii Street, Romania \\ e-mail: bogdan.tofan@uvvg.ro
}

\section{Adrian NIȚă}

"Babeș-Bolyai” University, Faculty of Geography, Gheorgheni Branch, Csiki Garden, Romania e-mail: nitaadrian@hotmail.com

\begin{abstract}
Citation: Tofan, G. B., \& Niță, A. (2019). Agricultural Land and Activities in Mureș County. Analele
\end{abstract} Universităţii din Oradea, Seria Geografie, 29(2), 114-123. https://doi.org/10.30892/auog.292112-829

\begin{abstract}
This study aims to analyse one of the most important land usages, that of agricultural land, which, in 2016, held $61.2 \%$ of the entire territory of Mureş County. Of all the land uses, the most extensive are arable lands (220,797 hectares), followed by pastures and hayfields (183,519 hectares), while orchards and vineyards occupied only 6,815 hectares. In terms of crops, grain is the most widespread (corn, wheat and rye, barley, oats), followed by fodder plants (alfa alfa, clover and corn), industrial plants (sunflower, canola, soybean, sugar beet), vegetables (tomato, cabbage, onion, edible root vegetables, pepper, cucumber), as well as potatoes and melons.
\end{abstract}

Key words: arable land, grain, horticulture, orchards and vineyards

* $\quad * \quad * \quad * \quad * \quad *$

\section{INTRODUCTION}

This paper aims to tackle one of the main economic sectors of Mureş county, agriculture, the primary provider of produce for the population and raw materials for the food and light industry. The above mentioned objective was preceded by an extensive analysis of a set of secondary sector components, published in 2018 and 2019 (see references). We also want emphasize that the paper was presented in front of the specialists attending the scientific conference dedicated to 100 years since the founding of the Geographic School of Cluj (Geographia Napocensis 100), section Social-economic Resources and Sustainable development.

\section{METHODOLOGICAL ASPECTS}

Based on the official statistical data provided by Mureş Department of Statistics and Mureş County Agricultural Office, I created spatial systematizations and interpretations, which were later converted into graphical and cartographical media, thus facilitating the understanding process of the territorial reality. Mureş County Statistics Book for 2016 also points out that the data series

\footnotetext{
${ }^{*}$ Corresponding Author
} 
regarding the agricultural surfaces based on usage remain „stuck” in 2014, until the cadaster of Romania is completed. Moreover, we consulted several studies which dealt with similar topics as our own (Cetină, 1981; Cocean et al., 2011; Cocean et al., 2013; Herman 2009a, b, 2010; Nimigeanu, 1996; Raboca et al., 2001; Păcurar, 2006; Pop, 1974; Şandru, 1978; Popovici \& Mihail, 1980; Șoneriu \& Mac, 1973; Tofan, 2013, 2018, 2019; etc.).

\section{GENERAL STRUCTURE OF FIELDS}

In 2016, the total surface area of Mureș County was 671,388 hectares, out of which 411,131 hectares $(61.2 \%)$ are agricultural land, while $31.2 \%$ (209,451 hectares) are forests, and water $1 \%$ (6,388 hectares). The "other surface" category $6.6 \%$ (44,418 hectares) includes land occupied by buildings $(3 \%, 19,921$ hectares $)$, communications routes $(1.6 \%, 10,806$ hectares $)$ and degraded and nonproductive land (2\%, 13,691 hectares). Agricultural land and activities are influenced by terrain, climate and soil, with arable land extending for more that a quarter of the entire county's surface area 32.8\% (220,797 hectares). Pastures reach 16.3\% (109,257 hectares), hayfields 11\% (74,262 hectares), orchards and nurseries $(0.8 \%, 5,151$ hectares. Vineyards and vine nurseries $(0.3 \%, 1,664$ hectares) are modestly represented, being concentrated mostly in the hinterland of Reghin and the Târnave Corridor.

One may conclude that arable land holds more that half $(53.7 \%)$ of the entire agricultural land in the county. Thusly, agricultural activities focus mostly on growing grain and fodder, which in turn stimulates the animal husbandry sector, mostly birds and swine.

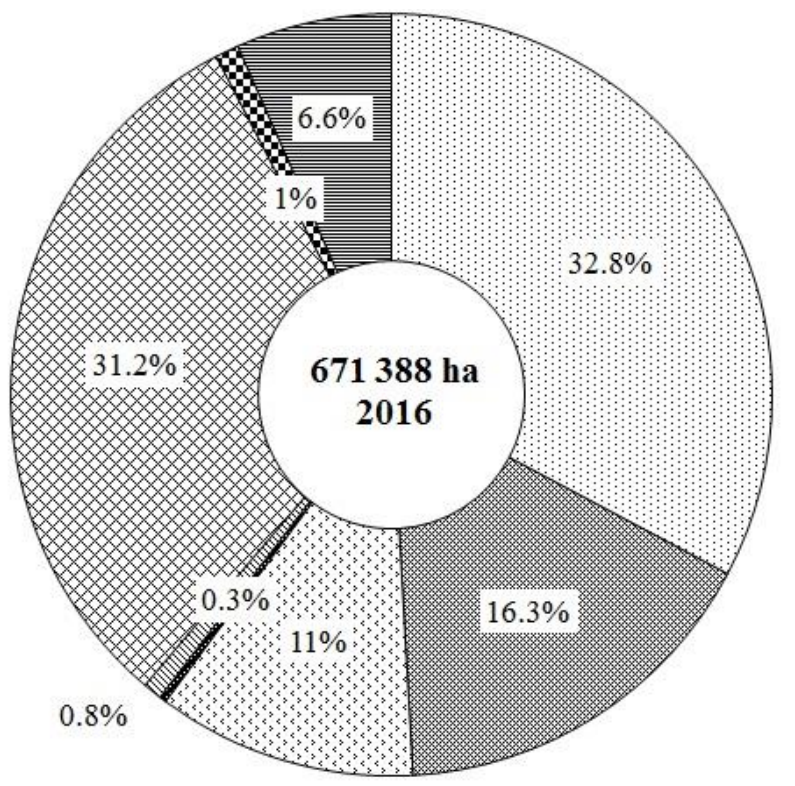

Arable

Meadows

Hay fields

Vineyards and viticulture nurseries

Orchards and fruit-growing nurseries

Forests and other surface with f.v.

Waters and swamps

Other surfaces' category

Figure 1. Mureș County. General land structure (agricultural, forests and other surfaces with forestry vegetation, waters and swamps and "other surfaces" category) and structure of agricultural fields (arable, pastures and hayfields, vineyards and viticulture nurseries, orchards and fruit-growing nurseries) in 2016 (f. v. $=$ forestry vegetation)

ARABLE LAND AND PLANTS CULTURE

Compared to the average percentage registered at county level (32.8\%, in 2016), and under the direct orographic influence, most arable lands are located in the western part of the county, in 
the rural areas of Mureș Plain (Sărmaș Plain): Valea Largă (75.7\%), Mădăraș (70.2\%), Band (69.5\%), Miheșu de Câmpie (67.2\%), Grebenișu de Câmpie (65.5\%), Pogăceaua (64.3\%), Șincai and Șăulia (64.2\%), Râciu și Sânger (63.3\%), Zau de Câmpie (63\%) and Pănet (60.5\%), and the sole agricultural town of the Transylvanian Plain, Sărmașu, where arable land recorded values of $61 \%$. Percentages above $60 \%$ were also found in two other communes (Sântana de Mureș, $71 \%$ and Cucerdea, 60.6\%), in an urban area located in Mureș Valley (Iernut, 65\%), as well as in Gănești Commune (60.6\%) - Târnava Mică Valley. Fewer arable lands (percentages below 10\%) are a characteristic of settlements located near or in Căliman and Gurghiu Mountains, for instance in Mureș Defile (Răstolița, 0.2\%; Lunca Bradului, 0.3\%; Stânceni, 1.1\% and Deda, 9.5\%); as well as Reghin Hills (Vătava, 4.1\%); Valea Gurghiului (Ibănești, 2.1\%) and the marginal areas of Sângeorgiu de Pădure-Sovata Hills (Sovata, 6.6\% and Chibed, 9.8\%).

In 2016, over half of the 220,797 hectares of arable land in the county were cultivated with grain (119,701 hectares), followed by fodder plants (48,412 hectares), technical plants $(17,447$ hectares) and vegetables, potatoes and melons (12,821 hectares). The remaining 22,416 hectares were used for cultivating strawberries (34 hectares), flowers and ornamental plants (52 hectares), while 22,330 hectares are categorised as unused farmland.

a) Grain growing extends on $54.2 \%$ of the county's arable land, mostly in lower areas, known as one of the bread baskets of the Transylvanian Depression (Pop, 2012, p. 185). Gentle hills are highly suitable for said crop, especially corn, $32.7 \%$, followed by wheat and rye, $14 \%$, barley, $3.7 \%$, oats, $2.6 \%$ and other cereals (triticale, millet, sorghum), with $1.2 \%$.

Corn is the apex crop (32.7\% of arable farmland), covering 72,231 hectares (2016). The average yield in Mureş County is roughly $4,500 \mathrm{~kg} /$ hectare. The largest surface areas cultivated with corn are in Mureş Plain (Band, 3,447 hectares; Pănet, 2,184 hectares; Zau de Câmpie, 2,039 hectares; Sânger, 2,040 hectares; Sărmaşu, 1,987 hectares; Valea Largă, 1,458 hectares and Miheşu de Câmpie, 1,056 hectares), in Mureş Valley (Iernut, 3,111 hectares; Cheţani, 1,633 hectares; Luduş, 1,560 hectares; Sânpaul, 1,132 hectares; Ogra, 1,090 hectares and Ernei, 1,051 hectares), as well as in lower basins of Niraj and Târnava Mică valleys (Bălăuşeri, 1,380 hectares; Adămuş, 1,373 hectares; Aţintiş, 1,253 hectares; Acăţari, 1,224 hectares; Bahnea, 1,033 hectares and Bichiş, 1,007 hectares). This is due to the presence of mollisols and clay soils, chemically and biologically suitable for such a plant, but only when agro-technical improvements are introduced (Pop, 2007, p. 180). At higher altitudes, due to the high extent of technical plants and improper weather conditions, corn cultivated farmland decreases considerably (below 50 hectares), in communes such as Chibed, Corunca, Eremitu, Stânceni and Lunca Bradului.

To increase the average production per hectare (Cetină, 1981, p.159), the authorities and private entrepreneurs introduced several hybrids, such as the ones developed by Pioneer Optimum AQUAmax (P9241, P9415, P9757, P9486, P9903), with a 114-124 day vegetation period, leading to more than $10,000 \mathrm{~kg} /$ hectare in Găneşti, Glodeni, Acăţari, etc.

Grain (30,463 hectares in 2016) has favourable development conditions especially in the lower areas of the county, where arable farmland exceeds 50\% (Band, Sărmaşu, Râciu, Sânpetru de Câmpie, Pogăceaua, Pănet, Miheșu de Câmpie, Iclănzel, Iernut, Luduş, Ungheni, Ernei etc), with average yields of roughly 4,000 kg/hectare. According to Mureş Agricultural and Rural Development Office, 2017 saw the highest production in the entire history of the county, 5,810 kg/hectare. In the mountainous area surrounding Mureş Defile, such crop is missing. However, low rentability caused by poor mechanization, lack of workforce and the agricultural market instability provoked a decrease by more than half in the cultivated farmland between 1990 and 2016. The main types of wheat found in Mureş are: Andrada, Apache, Apullum, Ardeal 1, Arieşan, Boema 1, Glosa KG Kungloria, Renan, Acteur, Bitop, Exotic, Midas, Othectareslom, Kristina, etc.

Almost the entire surface area cultivated with autumn type wheat, while hard wheat (Trtiticum durum) is cultivated in experimental patches (57 hectares). In higher areas, with poorer pedoclimatic conditions, people grow rye (Raboca et al., 2001, p. 41). However, said crop has 
considerably lost surface area (Popovici \& Mihectaresil, 1980, p. 176), reaching 193 hectares (2016), while the average yield being $2400 \mathrm{~kg} / \mathrm{hectare}$, mostly on private farmland.

Furthermore, many cultivate a hybrid between wheat and rye (triticale), used as animal fodder, beer malt and in alcohol production. A major advantage is its resistance to diseases and harsher climatic conditions (its does not require herbicides), while seeds open much sooner than other plants (Cocean et al., 2013, p. 206). Therefore, in 2016, there were 2,446 hectares of autumn triticale and 268 hectares of spring triticale, with an average county yield of roughly 2,500 $\mathrm{kg} /$ hectare. The largest farmland cultivated with triticale were recorded in Sângeorgiu de Pădure Hills (Miercurea Nirajului, 200 hectares, Bereni, 160 hectares and Sângeorgiu de Pădure, 104 hectares).

Barley was modestly represented in 2016, extending on 8,204 hectares (3.7\%) of the total arable land of the county (220,797 hectares). It is primarily used as animal fodder and in beer making. It is mostly cultivated in Sărmaşului Plain (Band, Iclănzel, Miheşu de Câmpie, Grebenişu de Câmpie), Mureş Valley (Gorneşti, Ogra, Luduş) as well as in the hills and valleys of Târnave (Băgaciu, Aţintiş), From 2006 to 2016, average county production increased from 2,236 kg/hectare to $3,387 \mathrm{~kg} /$ hectare.

Oats is mostly found in the cooler and wet areas of the eastern part of the county (Miercurea Nirajului, 395 hectares; Măgherani, 200 hectares; Hodac, 170 hectares; Suseni, 166 hectares; Breaza, 150 hectares; Aţinţiş, 118 hectares, etc), where soil fertility is lower. In 2016 it occupied 2.6\% (5,782 hectares) of the total arable farmland and yielded $2,437 \mathrm{~kg} /$ hectare. Large surfaces cultivated with oats can be found in lower areas, as said lands may find a superior usage as bearers of other plants (Lunca, 541 hectares; Tăureni, 176 hectares; Râciu, 150 hectares; Cozma and Iclănzel, 120 hectares). Production was around $2,000 \mathrm{~kg} /$ hectares and was used as horse fodder, but also as food for younglings and diabetics - flower, cereal and semolina.

Besides said (,main”) grain, other, secondary, grain crops are cultivated (Păcurar, 2006, p. 58), such as sorghum (82 hectares, out of which 60 hectares in Sântana de Mureş) and millet (32 hectares out of which 25 hectares in Reghin).

b) Fodder found optimal growth conditions in lower areas, but also at higher altitudes, and play a crucial role in the animal husbandry sector. In 2016, fodder plants claimed $22 \%(48,412$ hectares) of the county's arable land, mostly old and new perennial plants (16.8\%), followed by hay and green mass plants, and silo plants, both with $2.5 \%$. The most widespread perennial plants in the county are alfa-alfa and clover. The former increased in surface area in the last two decades due to the ever increasing need for fodder, but also due to its nutritional value, from 9,231 hectares (1990) to 18,890 hectares (2016). According to statistical data, the most extended areas were recorded in Ceuaşu de Câmpie (951 hectares, $24.8 \%$ of the commune's arable land), Râciu (946 hectares, 20.3\%), Sărmaşu (715 hectares, 15.4\%) and Band (695 hectares, 11.1\%).

Clover, more resilient to lower temperatures, but requiring a substantial amount of rainfall, lost almost half of its surface area (only 3,559 hectares in 2016), with cloverfields around Band, 420 hectares (largest surface in the county), as well as Ernei, Glodeni, Miercurea Nirajului, Găleşti, Batoş, Acăţari, etc., with areas measuring approximately 100-200 hectares. Other perennial plants cover 14668 hectares, and are present in 83 administrative-territorial units, mostly in the communes of Hodoşa ( 830 hectares), Şincai ( 800 hectares) and Sovata (675 hectares).

Yearly hay and green mass plants cover 5,710 hectares, with oat, rye, meslin, fodder peas, etc., found predominantly in the Transylvanian Plain (Glodeni, Fărăgău, Şincai, Sărmaşu, Sânpetru de Câmpie, etc) and the submountain depressions (Miercurea Nirajului, Eremitu, Bereni, etc).

Silo plants (5,585 hectares) are dominated (98\%) by silo corn (5,461 hectares), while root fodder plants (fodder beet and courgette) occupy 124 hectares.

c) Technical plants occupy the third largest agricultural area $(17,447$ hectares, $8 \%$ of the cultivated arable land, in 2016), with three groups: oil plants (sunflower, 5,244 hectares; rapeseed, 4,974 hectares, and soybean, 4,368 hectares), other industrial plants (sugar beet, 2,299 hectares, millet, 204 hectares, tobacco, 98 hectares, sorghum, 88 hectares, and energy willow, 36 hectares) and 
medicinal and aromatic plants, with 136 hectares. In the 1990s, large areas (3,494 hectares) were covered with textile plants. However, hemp and flaxseed are no longer cultivated.

Sunflower, with an average temperature of $8^{0} \mathrm{C}$ as its fruiting limit (Nimigeanu 1996, p. 198), covers large areas (100-300 hectares) in the western, warmer extremity of the county (Sărmaşu, Band, Grebenişu de Câmpie, Miheşu de Câmpie, Ogra, Pogăceaua, Râciu, Sânpetru de Câmpie), as well as areas around: Târnăveni, Iernut, Luduş, Ungheni, Adămuş, Ibăneşti, Suplac, Viiş̧oara, etc, with a total of 5,244 hectares (2.4\% of the arable land, in 2016). Taking into account the ever increasing cooking oil of the population, Mureş County experienced an increase in sunflower yield from $556 \mathrm{~kg} /$ hectare in 1990 to $2,189 \mathrm{~kg} /$ hectare in 2016, mostly on privately owned land.

Rapeseed is increasingly used in the production of industrial products (mechanical lubricant, biofuel, cosmetics and pharmaceutics), as well as in the food industry (extravirgin oil and margarine), and animal fodder (Geografia României, II, 1984, p. 343). Land covered by rapeseed crops increased from 303 hectares in 2007 to 4,974 hectares in 2016 (2.2\% of the county's arable land). The largest extent - Mureş Valley (Iernut, 654 hectares; Sânpaul, 382 hectares; Ungheni, 371 hectares and Ogra, 315 hectares). Another extensively used oil plant is the soybean. In 2016, soybean registered a percentage of $2 \%$ in Mureş (4,368 hectares), with an average growth per hectare of over three times from 1990 to 2016 (2,010 kg/hectares in 2016). Important soybean production centres - Iernut, Bahnea, Râciu, Pogăceaua, Băgaciu and Târnăveni.

Sugar beet, with $1 \%$ of the county arable land, is cultivated on large plots of land in the Transylvanian Plain (Band, Pogăceaua), Mureş Valley (Luduş area) and Târnave Plateau (Târnăveni, Daneş, Găneşti), where pedoclimatic conditions are perfect for said crop. In order to reduce production costs (Şandru, 1978, p. 227), there were several large sugar processing units in TârguMureş (Sugar Beet Processing Enterprise, rebranded Zamur after 1990) and Luduş (the former "Zahărul" Luduş plant, privatized in 2013 and sold to the French Tereos Consortium), with a processing capacity of 4,000 tonnes/day (Tofan \& Niţă, 2018, p. 50). In the last two decades, sugar beet production declined considerably (from 10,504 hectares in 1996 to 2,299 hectares in 2016), due to the introduction of the sugar quota, price liberalizations, and high fertilization costs. This contributed to the closure of many plants, among them the one located in Târgu-Mureş.

Hops fields are found solely on the southern exposure slopes of Târnava Mare Valley (area around Sighişoara), occupying 204 ha (Sighişoara 95 ha; Saschiz 60 ha and Daneş 49 ha). It is mostly used in beer making, and a small part in pharmaceutics.

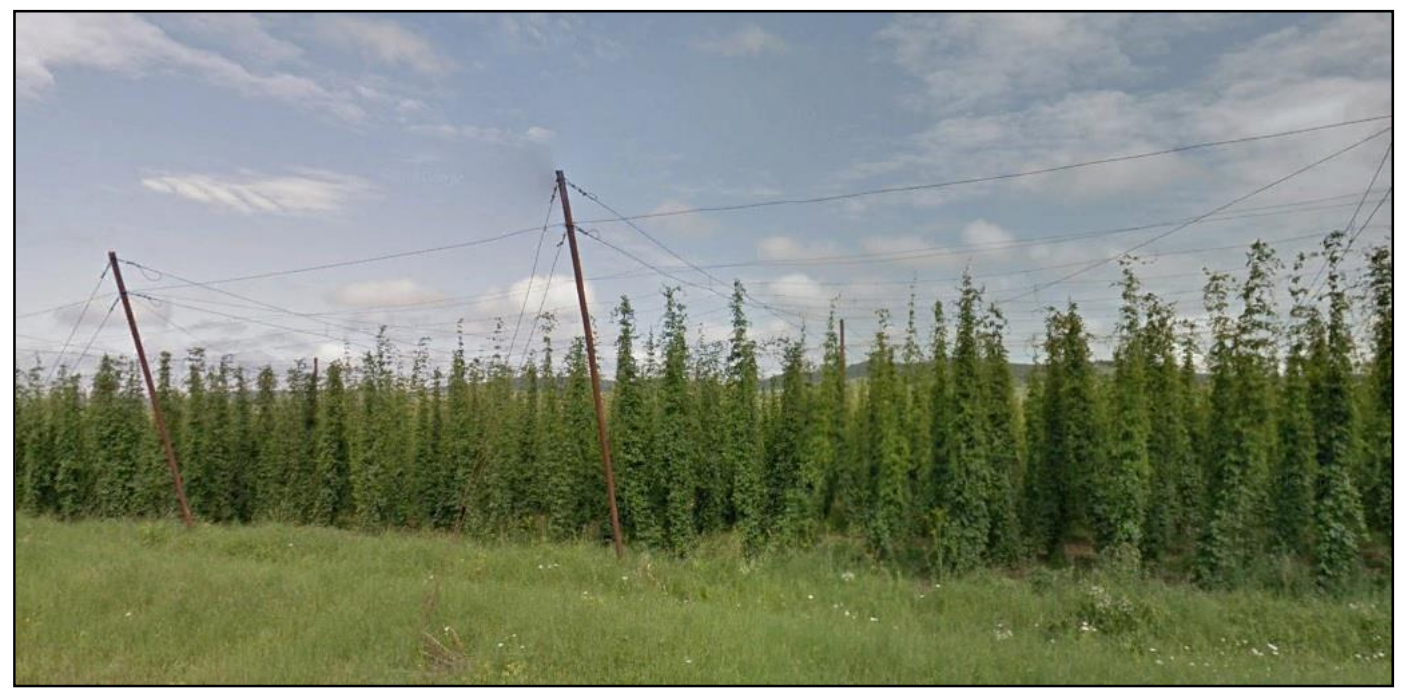

Figure 2. Millet growing in Târnava Mare Corridor, Daneş 
Tobacco has experienced a steady decline over the years, caused by the shutdown of processing plants. This led to a reduction of acreage, from 1,159 ha in 1990, to 98 ha in 2016 , the entire production being exported abroad. Two types are cultivated in the eastern part of the Transylvanian Plain (Virginia, with a medium concentration of nicotine, and Havana, for cigars and cigarillos) (Pop, 1974, p. 240).

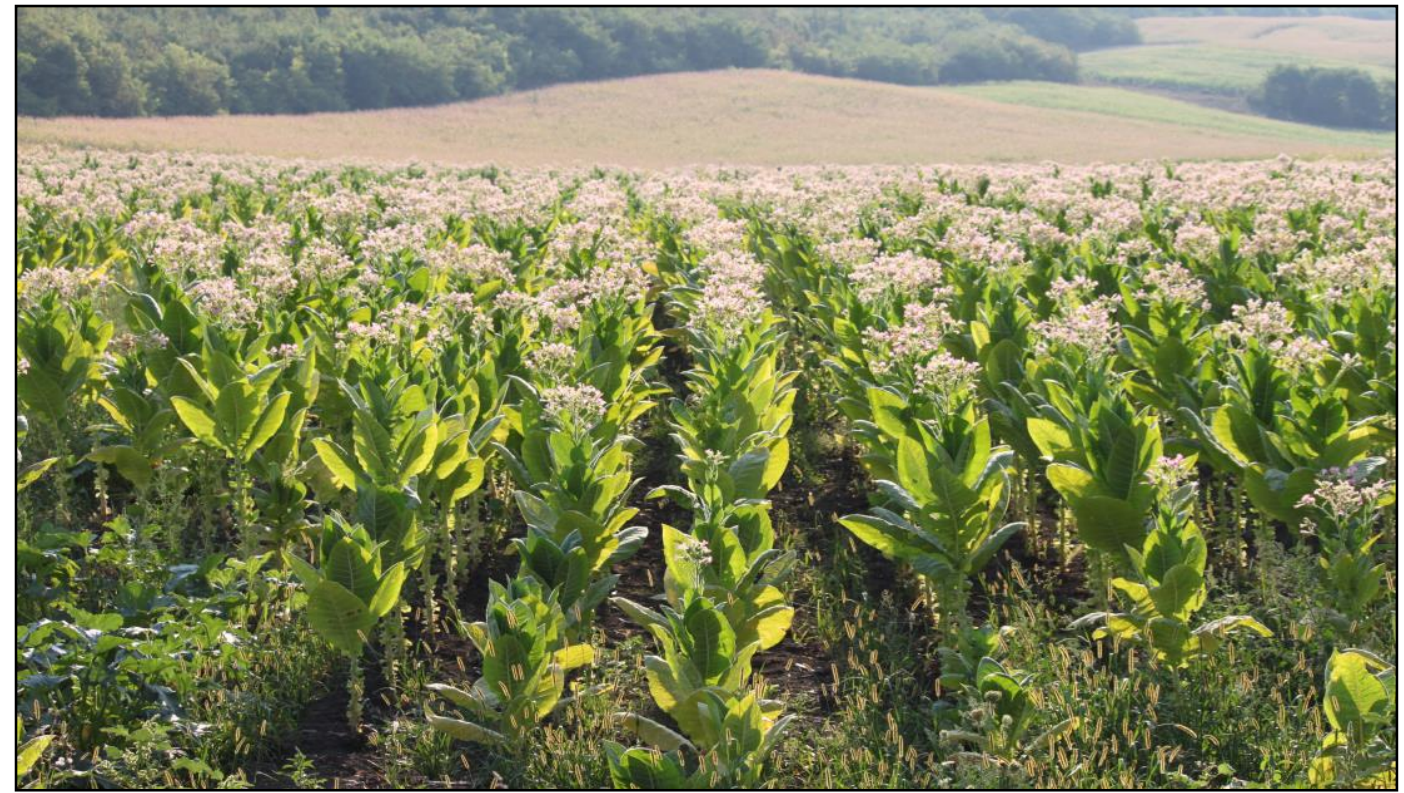

Figure 3. Tobacco growing in Transylvanian plain, Sărmăşel Gară

Last but not least, there are plots of land cultivated with sorghum, used for manufacturing brooms ( $88 \mathrm{ha}$ ), and energy willow (36 ha), used for making pellets.

The last group of technical plants is represented by medicinal and aromatic plants, grown on a surface area of 136 ha. However, the vast majority of plants are harvested from spontaneous flora, with some processing units functioning in Ibăneşti, Reghin and Sovata, which produce a multitude of tea products.

d) Vegetables and potatoes are crucial for man's nutritions needs, as well as for the entire food industry (Nimigeanu, 1996, p. 207). In 2016, the surface area cultivated with vegetables and potata reached 12,821 hectares $(5.8 \%$ of the county's arable land), with emphasis on vegetables $(3.2 \%)$, while potatoes $2.5 \%$.

Vegetable crops enjoy the very best natural conditions, especially along the valleys and terraces of Mureş, Niraj and Târnave rivers, with wet alluvial soils, which can be effortlessly cultivated. The surface area covered with vegetables was 7,134 hectares in 2016, with just 10 hectares integrated in the intensive agricultural system (greenhouse). Most of the fresh produce are grown outside, in family farms, with a wide array of species, especially tomatoes, 1,246 ha; but also pepper, 560 ha and eggplant, 250 ha), onion, 1,032 ha and garlic, 313 ha), white and red cabbage, 1,209 ha, cauliflower, 115 ha), root vegetables with 1,016 ha (largest extent - carrot, 660 ha; followed by parsley, radish, parsnip, celery and red beet), pulse (seed beans, 112 ha; seed peas, 355 ha; pod beans, 317 ha and pod peas, 176 ha), gourd (cucumber, 465 ha, green melon, 92 ha, yellow melon 64 ha) and leaf vegetables (salad, spinach, 435 ha).

Mureş County contains three large vegetable growing regions, the first located in the Transylvanian Plain (Mureş Plain), and the second along the valleys of Târnava Mică and Niraj. 
Two additional regions were identified - the submountain hills and depressions (Reghin Hills and Sângeorgiu de Pădure Hills) and Mureș Corridor.

The Transylvanian Plain, and especially its sourthern part (Mureş Plain), is highly diversified in terms of vegetable crops, mostly around Band, Grebenişu de Câmpie, Ceuaşu de Câmpie and Râciu, where almost all previously mentioned vegetables are grown (carrot, parsley, celery, beet, onion, garlic, peas, cabbage, cauliflower, cucumber, tomato, pepper, eggplant).

The Târnava Mică and Niraj Corridors comprise of large plots of land cultivated with vegetables - around the town of Târnăveni (tomatoes, 50 hectares, $1.8 \%$ of the total arable land; cabbage, 27 hectares, $1.0 \%$; root vegetables , 23 hectares, $0.8 \%$; onion, 21 hectares, $0.8 \%$; pepper, 15 hectares, $0.5 \%$; cauliflower, 8 hectares, $0.2 \%$ and eggplant 5 hectares, $0.2 \%$ ), as well as some rural areas (Adămuş, Mica, Bahnea, Suplac, Crăciuneşti, Gheorghe Doja, Acăţari, Găleşti, Vărgata), with roughly the same range of crops.

The last two smaller areas include parts of Reghin Hills and Sângeorgiu de Pădure Hills, best known for the cultivation of the red onion of Buzău (also known as "water onion"), garlic, cabbage, tomatoes, cucumbers and peppers (around Reghin), in centres such as: Reghin, Ideciu de Jos, Suseni, Brâncoveneşti, Hodac şi Ibăneşti, Chibed, and Bălăuşeri.

Mureş Valley is highly favourable for the cultivation of cabbage, beans, bulb vegetables and as well as tomatoes, eggplants and peppers, in areas such as Iernut, Luduş, Gorneşti, Cuci, Cheţani and Bogata.

Potato cultivation (5,531 hectares, $2.5 \%$ of the arable land in 2016) finds proper conditions in hill areas, on gentle slopes, prefering a cool and damp climate. Potato fields can be found across the entirety of the county. It is represented almost exclusively by autumn potatoes $(91.3 \%)$, while early and summer potatoes are mostly grown in lower areas and in the vicinity of urban areas, alongside vegetables (Şoneriu, Mac, 1973, p. 137). The largest autmn potato fields are found in the towns of Band (280 hectares), Bălăuşeri (216 hectares), Ernei (185 hectares), Acăţari (152 hectares), Luduş (140 hectares) and Ibăneşti (130 hectares). In terms of average potato yield per county, between 2006-2016, the largest quantity was recorded in $2016(19,386 \mathrm{~kg} /$ hectare $)$ and the lowest in 2012, only $9,724 \mathrm{~kg} / \mathrm{hectare}$.

\section{Pastures and hayfields}

This land category forms the fodder basis for animal husbandry. Compared to the county surface area, it holds the second place after arable land, with $27.3 \%$ (183,519 hectares). Pastures have a relative value of $16.3 \%$ (109,257 hectares), while hayfields $11 \%$ (74,262 hectares).

a) Pastures register different values both in terms of nutritional content as well as in their territorial distribution across the county. Most territorial units record values between 10-20\% (57), the lowest percentages being found in the City of Târgu-Mureş $(2.2 \%, 110$ hectares), Crăciuneşti (3\%, 148 hectares), Reghin (5.7\%, 321 hectares) and Cristeşti (5.7\%, 76 hectares), and the highest in Chibed (43.2\%, 1,580 hectares), Vețca (33.3\%, 1,249 hectares) and Brâncoveneşti (31.5\%, 2,756 hectares). Areas with $20-30 \%$ can be found solely in two communes located in the TopliţaDeda Corridor (Răstoliţa, 5,032 hectares and Lunca Bradului, 4,759 hectares) (G. B. Tofan, 2014, p. 96), as well as in the marginal submountain depressions of Reghin Hills (Gurghiu, 2,696 hectares, Hodac, 2,121 hectares and Vătava 2,084), Northern Hârtibaciu Plateau (Apold, 2,595 hectares) and Târnava Mare Valley (Daneş, 2,102 hectares).

b) Unlike natural fields, hayfields have an sizeable plant richness and a higher nutritional value for animals, but their surface area remains low (74,262 hectares). Most are found in Reghin Hills (Deda, 33\%, 2,524 hectares, the highest percentage in the county), Aluniş (32\%), Ideciu de Jos (29\%), Solovăstru (28\%), Ruşii-Munţi (27\%), Vătava (26\%), Brâncoveneşti (24\%) and Beica de Jos (22\%), as well as in the Târnava Mica Valley, at Sărăţeni (29\%) and Adămuş (23\%). The lowest percentages were recorded in the Mureş Plain and the valleys of Mureş and Niraj, meaning that 61 of the total 102 administrative-territorial units in the county have relative values of below 10\% (Târgu-Mureş, 2.2\%, 108 hectares, the lowest in the county). This is partly due to a larger 
extension of arable lands (such as the case of Sântana de Mureş, where there were no records of hayfields), as well as to the presence of forested and pasture areas in the mountains.

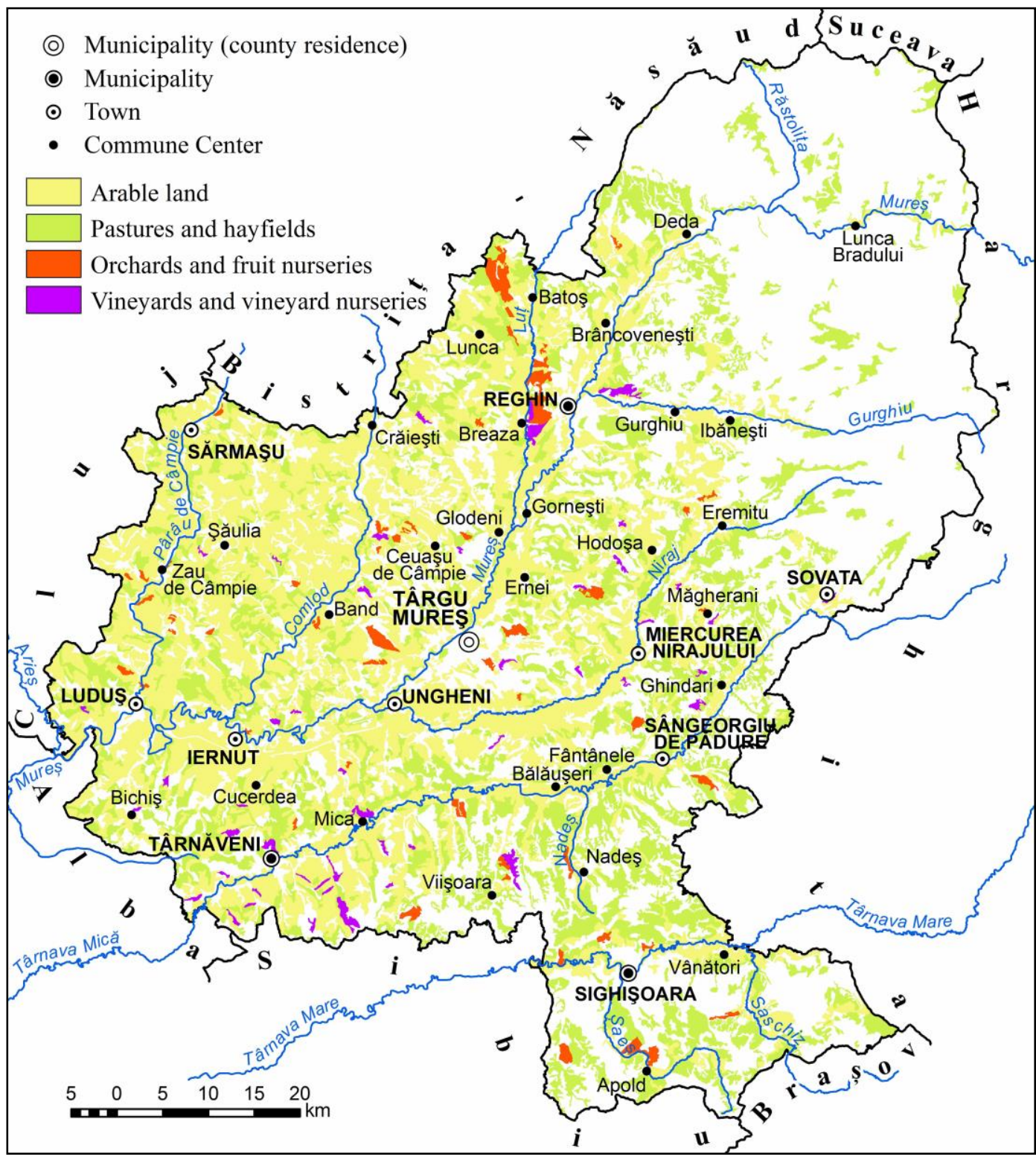

Figure 4. Mureş County. Agricultural land usage map Source: after Corine Land Cover 2016

\section{Orchards and nurseries}

In some parts of Mureş County, pomiculture has been blessed with favourable oropedoclimatic conditions, as well as a certain tradition. In 2016, compared to the entire surface area of the county, orchards covered $0.8 \%$ (5,151 hectares), half being active (2,694 hectares), the remaining hectares being young orchards, nurseries, and decrepit orchards. Thusly, the higher area covering the eastern part of the county hosts the fruit growing region of Reghin, with a surface of 
1,473 hectares (Batoş, 765 hectares; Reghin, 511 hectares and Breaza, 197 hectares). The area is dominated by apple cultivars, such as Golden Delicious, Jonagold, Pinova, Jonathan, Idared, Red Delicious, Florina and Generos. Some areas are covered by plum, cherry and pear trees. Moreover, there are other, smaller, fruit growing areas in the Transylvanian Plain (Pănet, 444 hectares and Ceuaşu de Câmpie, 145 hectares) and Târnave Plateau (Apold, 436 hectares; Suplac, 215 hectares; Livezeni, 203 hectares; Bahnea, 140 hectares; Daneş, 120 hectares, etc.). These are dominated by plum trees, followed by apple, pear and walnut, and, in some areas, even peach and apricot trees.

\section{Vineyards and nurseries}

In 1990, the surface area covered with vineyards was 4,916 hectares. However, following the retrocession process, the vineyards dropped to 1,664 hectares $(0.3 \%$ of the county territory) in 2016, with 964 hectares of active vineyards (690 hectares graft and 274 hybrid) and 4 hectares of vineyard nurseries. Taking into account the exposure, orography, climate, soil cover and structure, the vineyards compose a relatively large wine region, Târnave Wine Country. It is one of the oldest and most well-known wine areas in the country, covering the sunlit slopes of Mureş Corridor and parts of the Târnave valleys (Geografia României, II, 1984, p. 359). Mureş County has has three wine producing centres: Târnăveni (encompassing the communes of Adămuş, Băgaciu, Găneşti, Mica, Suplac, and Bahnea), Zagăr and Nirajului Valley (Zagăr, Viişoara, Coroisânmartin, Bălăuşeri, Fântânele, Nadeş, Acăţari, and Crăciuneşti). Grapes are mostly used to produce wine, with sparkling wines, both white (Gewurztraminer, Chardonnay, Pinot Gris, Muscat Ottonel, Sauvignon, Neuburger, Riesling Italian, Riesling de Rhin, Fetească Regală, Fetească Albă, Furmint), and red (Cabernet Sauvignon, Pinot Noir, Fetească Neagră, Syrah, Merlot) (Şoneriu, Mac, 1973, p. 138). Other wine making centres can be found in Batoş, Ceuaşu de Câmpie (village of Culpiu), Band and Mădăraş, part of Lechinţa, which, alongside Târnave Area, produces excellent wines.

\section{CONCLUSIONS}

In 2016, out of the entire surface area of Mureş County (671,388 hectares), $61.2 \%$ or 411,131 hectares or the vast majority was agricultural land. Out of this, more than half was arable $(220,797$ hectares), followed by pastures and hayfields (183,519 hectares). The remaining land was occupied by orchards and vineyards (6,815 hectares). Arable land was most extended in the western part of the county, in the Mureş Plain and Corridor, where grain plant growing is the most mature $(119,701$ hectares), thus making the region one of the ,bread baskets of Transylvania”. There are also considerable areas cultivated with fodder plants (48,412 hectares), which supports a strong animal husbandry sector.

I identified a decline in hemp, sugar beet, millet and tobacco plantations, while the high demand for cooking oil led to an extension of sunflower, rapeseed and soy plantations. Vegetable and potato fields are found across the entire county, with four large cultivation areas: Mureș Plain and Târnava Mică-Nirajului (more extended), as well as Mureş Corridor and Reghin - Sângeorgiu de Pădure Hills (less extended), where production are traded as well as used in house.

Pastures and hayfields are mostly on the eastern hills and depressions (Reghin Hills), as well as in the mountains (Topliţa-Deda Defile), (Tofan \& Păcurar, 2013, p. 335), less so in lower areas. Orchards and vineyards declined extensively in the past three decades due to the retrocession process, as the new owners failed to maintain and reinvigorate said plantations, which in turn led to low yields.

Geographically speaking, pomiculture is more extended in the Reghin Basin, while viticulture in the Târnave Area, with centers in Târnăveni, Zagăr and Valea Nirajului, as well as Lechinţa Areas, mostly in Batoş, Ceuaşu de Câmpie, Band and Mădăraş. 


\section{REFERENCES}

Cetină, E. (1981). Probleme de Geografie economică mondială [World Economic Geography problems], Editura Didactică şi Pedagogică, Bucureşti.

Cocean, P., Boțan, C. N., Ilovan, O. R. (2011). Judeţele României. Județul Bistriţa-Năsăud [Counties of Romania. BistriţaNăsăud County], Editura Academiei Române, București.

Cocean, P., Niță, A., Dombay, Șt. (2013). Județele României. Județul Harghita [Counties of Romania. Harghita County], Editura Academiei Române, București.

Herman, G.V. (2009a). Omul şi modificările antropice din Câmpia Someşului [The man and anthropogenic changes in Somes Plain], Editura Universităţii din Oradea, 227 pag., ISBN 978-973-759-981-0, Oradea.

Herman, G.V. (2009b). Ways of anthropic intervention in the Someşului Plain. Analele Universităţii din Oradea, Seria Geografie, 20(1): 120-126.

Herman, G.V. (2010). Structure and share of agricultural lands, key indicators in quantifying the anthropogenic impact in the Somes Plain. Analele Universităţii din Oradea Fascicula Construcţii şi Instalaţii Hidroedilitare, 13(2): 153-159.

Nimigeanu, V. (1996). România. Geografie Umană [Romania. Human Geography], Editura Univ. „Al. I. Cuza”, Iaşi.

Păcurar, Al. (2006). Geografie economică mondială [World Economic Geography], Editura Presa Universitară Clujeană.

Pop, P. Gr. (1974). România. Geografie economică [Romania. Economic Geography], partea a II-a, Institutul Pedagogic din Oradea, Facultatea de Istorie-Egeografie, Oradea.

Pop, P. Gr. (2007). Judeţele României. Judeţul Cluj [Counties of Romania. Cluj County], Editura Academiei Române, Bucureşti. Pop, P. Gr. (2012). Depresiunea Transilvaniei [Transylvania Depression], Editura Presa Universitară Clujeană, Cluj-Napoca.

Popovici, I., Mihail, M. (1980). România. Geografie economică [Romania. Economic Geography], Editura Didactică şi Pedagogică, Bucureşti.

Raboca, N., Ciangă, N., Păcurar, Al. (2001). Geografie Economică [Economic Geography], Editura „Vasile Goldiş” University Press, Arad.

Şandru, I. (1978). România. Geografie Economică [Romania. Economic Geography], ediţia a II-a, Editura Didactică şi Pedagogică, Bucureşti.

Șoneriu, I., Mac, I. (1973). Județul Mureș [Mureș County], Editura Academiei R.S. R, București.

Tofan, G. B. (2014), Defileul Mureșului. Studiu de Geografie Umană [Mureș Defile. Human Geograhy Study], Editura Presa Universitară Clujeană, Cluj-Napoca.

Tofan, G. B., Niță, A. (2018). Industrial activities in Mureș County, Analele Universității din Oradea, Seria Geografie, 28 (2):36-53.

Tofan, G. B., Niță, A. (2019). Industrial activities in Mureș County (part II), Analele Universităţii din Oradea, Seria Geografie, 29 (1): 30-39.

Tofan, G. B., Păcurar, B. N. (2013), Serveral aspects regarding the specific activities from Mureş Defile, Analele Universității din Oradea, Seria Geografie, 23 (2):333-347.

*** (1984). Geografia României, II, Geografie Umană şi Economică [Romanian Geography, II. Human Geography and Economic], Editura Academiei R. S. România, Bucureşti.

*** (2012). Reactualizarea Planului de amenajare a teritoriului judeţean, judeţul Mureş, partea I, Analiza situaţiei existente, vol. V, Agricultura, industria, serviciile. Turismul, patrimoniul cultural, resurse umane, analiza firmelor, proiectant: Universitatea „Babeş-Bolyai” Cluj-Napoca, Facultatea de Geografie, Cluj-Napoca.

*** http://www.mures.insse.ro, accesed: $14^{\text {th }}$ december 2018.

*** http://www.dadr-mures.ro, accesed: $14^{\text {th }}$ december 2018.

Submitted:

Octomber 05, 2019
Revised:

Octomber 25, 2019
Accepted and published online

November 11, 2019 